\title{
Versatile Microwave-Assisted and Lanthanum Chloride Catalysed Synthesis of Polysubstituted Imidazoles Using Urea/Thiourea as Benign Source of Ammonia
}

\author{
MOHAMMAD REZA MANAFI ${ }^{1, *}$, PEDRAM MANAFI $^{2}$, AND MOHAMMAD $^{2}$ \\ REZA KALAEE ${ }^{3}$
}

${ }^{1}$ Department of Applied Chemistry, Islamic Azad University, South Tehran Branch, Tehran, Iran.

${ }^{2}$ Iran Polymer and Petrochemical Institute, P.O. Box: 14965/115, Tehran, Iran.

${ }^{3}$ Department of Polymer Engineering, Islamic Azad University, South Tehran Branch,

Tehran, Iran.

mr_manafi@azad.ac.ir

Received 20 September 2011; Accepted 08 November 2011

\begin{abstract}
Lanthanum chloride was found to be an effective catalyst for the facile and one-pot synthesis of polysubstituted imidazoles under solvent free condition in excellent yields. This method elucidates urea/thiourea, as an environmentally benign source of ammonia for the synthesis of polysubstituted imidazoles. The work-up procedure is very simple and the products don't require further purification.
\end{abstract}

Keywords: Microwave-assisted, Solvent free, Lanthanum chloride, polysubstituted imidazoles, benign source.

\section{Introduction}

Imidazoles, an important class of heterocyclic compounds, are well documented for both their biological activity as well as chemical properties. They are known to exhibit a wide range of biological activities such as p38, MAP kinase, B-Raf kinase, cyclooxygenase-2 (COX-2), and interleukin-1 (IL-1) inhibition. 1-4 Appropriately, substituted imidazoles are extensively used as canabinoid receptor antagonists, antibacterial and anti-tumor agents, pesticides and also modulators of P-glycoprotein (P-gp)-mediated multidrug resistance (MDR). ${ }^{5-7}$

So far, several synthetic methods have been reported for the preparation of 1,2,4,5tetrasubstituted imidazoles, in which aldehydes ,1,2-diketones, urea/thiourea , and amines 
condensed in the presence of several catalysts. Several catalyst have been used in the most common synthetic methods involve: molecular iodine, ${ }^{8}$ heteropolyacid, ${ }^{9} \mathrm{HClO} 4 . \mathrm{SiO} 2,{ }^{10}$ BF3.SiO2, ${ }^{11} \mathrm{FeCl} 3.6 \mathrm{H} 2 \mathrm{O},{ }^{12}$ silica gel/NaHSO $4,{ }^{13}$ and L-proline. ${ }^{14}$

The application of microwave irradiation in organic chemistry is increasingly recognized in recent years. Also microwave-promoted solid-phase heterogeneous reactions have become popular among synthetic organic chemists because of their higher degrees of selectivity, enhanced reaction rates as well as manipulative simplicity. Moreover this method has emerged as a powerful technique to promote cyclocondensation reactions in imidazoles preparation. ${ }^{15}$ Recently, the solid-phase synthesis of aza heterocycles using urea/thiourea as an efficient source of ammonia under microwave irradiation it has been reported. ${ }^{16}$

Knowing the importance of microwave-promoted solid-phase heterogeneous reactions, application of urea/thiourea as an efficient source of ammonia under microwave irradiation and usage of lanthanum chloride as a catalyst in several reactions, ${ }^{17}$ we have focused on improving the synthesis of polysubstituted imidazoles bearing in mind new synthetic methodologies.

In this letter we report a facile synthesis of polysubstituted imidazoles 5a-i in 82-94\% yields via a one-pot, four-component reaction between 1,2-diketones 1,aldehydes $\mathbf{2}$, urea/thiourea $\mathbf{3}$, and amines $\mathbf{4}$ under solvent free condition in microwave irradiation (Scheme $1)$.

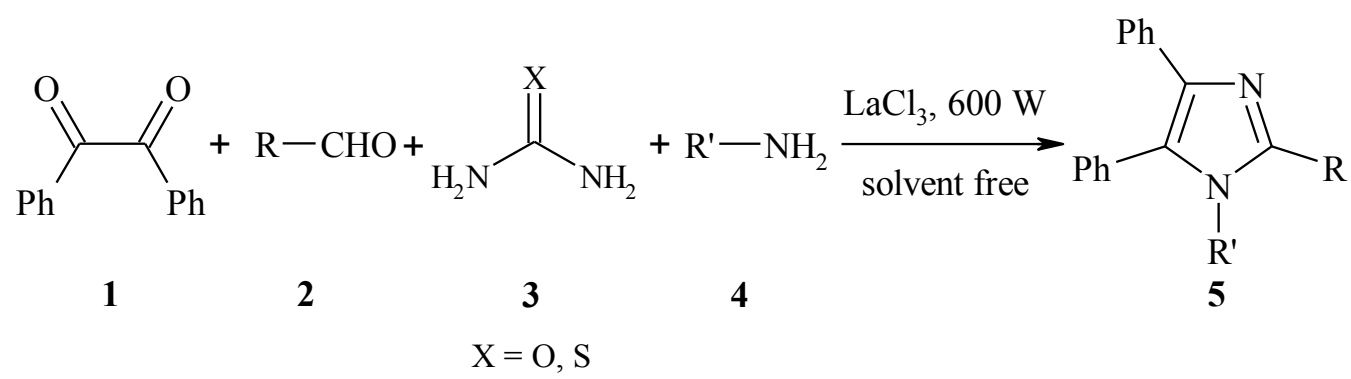

Scheme 1. $\mathrm{LaCl}_{3}$ catalyzed synthesis of imidazoles.

\section{Experimental}

All Chemicals were obtained from Merck and Aldrich chemical companies. All reactions were monitored by thin layer chromatography (TLC) using silica-coated plates. All of the products were identified by comparison of their physical and spectral data with those of authentic samples. IR spectra were recorded on a Jasco IR-680 spectrophotometer. ${ }^{1} \mathrm{H}$ NMR spectra were achieved with a Bruker-Arance AQS 500.1 MHz. The ${ }^{13} \mathrm{C}$ NMR spectra were recorded in DMSO- $d_{6}$ on a Bruker-Arance spectrometer operating at $125.8 \mathrm{MHz}$.

\section{General procedure for the preparation of 1,2,4,5-tetrasubstituted imidazoles}

A mixture of benzil $(1 \mathrm{mmol})$, urea/thiourea $(2 \mathrm{mmol})$, appropriate aldehyde $(1.2 \mathrm{mmol})$, appropriate amine $(1 \mathrm{mmol})$ and lanthanum chloride $(35 \mathrm{mmol} \%)$ were placed in an Erlenmeyer flask. The mixture was placed in a microwave oven and irradiated for a $4 \mathrm{~min}$ at 
a time. After each irradiation reaction mixture was removed from the microwave oven for shaking and checking by TLC. The total period of microwave irradiation was determined by TLC. After reaction completion, ethanol was added to the reaction mixture and catalyst was removed by filtration. The filtrate was poured into the crushed ice water and the resulting precipitate was purified by silica gel short column with $n$-hexane-ethylacetate(1:2) as eluent.

\section{Typical spectral data}

\section{1,2,4,5-Tetraphenyl-1H-imidazole (5a)}

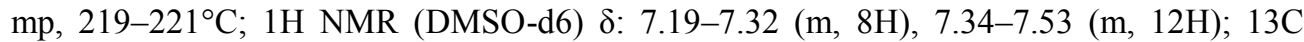
NMR (DMSO-d6) $\delta: 123.8,124.2,124.9,127.1,128.2,129.3,129.8,130.7,133.0,134.4$, 137.4, 139.2, 139.3, 139.5, 139.7, 140.3, 144.9. 2-(4-Nitrophenyl)-4,5-diphenyl-1-p-tolyl1H-imidazole (5d): mp, $219^{\circ} \mathrm{C}$; $1 \mathrm{H}$ NMR (DMSO-d6) $\delta: 2.15$ (s, 3H, CH3), 7.18 (d, J = 7.7 $\mathrm{Hz}, 2 \mathrm{H}, 2 \mathrm{CH}), 7.19-7.31$ (m, 6H, 6 CH), 7.34 (d, J = 8.1 Hz, 2H, 2CH), 7.35-7.39 (m, 4H, 4 $\mathrm{CH}), 7.42$ (d, J = 8.1 Hz, 2H, 2CH), 7.47 (d, J = 7.7 Hz, 2H, 2CH). 13C NMR (DMSO-d6) $\delta: 21.4,123.2,124.9,127.5,128.7,129.3,129.4,129.6,131.8,133.7,134.2,134.5,137.1$, $137.4,145.2,147.6,148.7$.

\section{2-(4-Nitrophenyl)-4,5-diphenyl-1-p-tolyl-1H-imidazole (5d)}

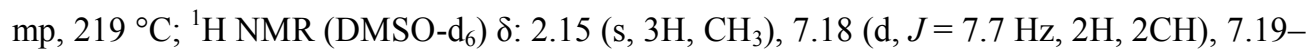
$7.31(\mathrm{~m}, 6 \mathrm{H}, 6 \mathrm{CH}), 7.34(\mathrm{~d}, J=8.1 \mathrm{~Hz}, 2 \mathrm{H}, 2 \mathrm{CH}), 7.35-7.39(\mathrm{~m}, 4 \mathrm{H}, 4 \mathrm{CH}), 7.42(\mathrm{~d}, J=$ $8.1 \mathrm{~Hz}, 2 \mathrm{H}, 2 \mathrm{CH}), 7.47(\mathrm{~d}, J=7.7 \mathrm{~Hz}, 2 \mathrm{H}, 2 \mathrm{CH}) .{ }^{13} \mathrm{C}$ NMR $\left(\mathrm{DMSO}_{-} \mathrm{d}_{6}\right) \delta: 21.4,123.2$, $124.9,127.5,128.7,129.3,129.4,129.6,131.8,133.7,134.2,134.5,137.1,137.4,145.2$, 147.6, 148.7 .

\section{Results and Discussion}

Initially, in order to optimize the catalyst, the reaction of benzaldehyde, benzil, urea/thiourea and aniline were screened in the presence of different Lewis acids $(35 \mathrm{~mol} \%)$ in solvent-free conditions and under microwave irradiation (Table 1).

Table 1. Screening of some acidic catalysts for model reaction under microwave irradiation ${ }^{\mathrm{a}}$.

\begin{tabular}{ccccc}
\hline Entry & Catalyst & Temperature $\left({ }^{\circ} \mathrm{C}\right)$ & Time $(\min )$ & Yield $(\%)^{\mathrm{b}}$ \\
\hline $\mathbf{1}$ & $\mathrm{K}_{5} \mathrm{CoW}_{12} \mathrm{O}_{40} \cdot 3 \mathrm{H}_{2} \mathrm{O}$ & 150 & 4 & 54 \\
$\mathbf{2}$ & $\mathrm{InCl}_{3} \cdot 3 \mathrm{H}_{2} \mathrm{O}$ & 150 & 4 & 64 \\
$\mathbf{3}$ & $\mathrm{CeCl}_{3} \cdot 7 \mathrm{H}_{2} \mathrm{O}$ & 150 & 4 & 72 \\
$\mathbf{4}$ & $\mathrm{NiCl}_{2} \cdot 6 \mathrm{H}_{2} \mathrm{O}$ & 150 & 4 & 60 \\
$\mathbf{5}$ & $\mathrm{FeCl}_{3} \cdot 3 \mathrm{H}_{2} \mathrm{O}$ & 150 & 4 & 56 \\
$\mathbf{6}$ & $\mathrm{ZnCl}_{2}$ & 150 & 4 & 68 \\
$\mathbf{7}$ & $\mathrm{LaCl}_{3}$ & 150 & 4 & 82
\end{tabular}

\footnotetext{
${ }^{\mathrm{a}}$ Reaction condition: Benzaldehyde $(1.2 \mathrm{mmol})$, Benzil $(1 \mathrm{mmol})$, Urea/thiourea $(2 \mathrm{mmol})$ and aniline ( $1 \mathrm{mmol}$ ) in presence of catalyst. The experiments were performed using a microwave oven (ETHOS 1600 , Milestone with a power of $600 \mathrm{~W}$ specially designed for organic synthesis) at $150{ }^{\circ} \mathrm{C}$.

${ }^{\mathrm{b}}$ Isolated yield after recrystallization.
} 
Thus a mixture of a benzil $\mathbf{1}$, an aldehyde $\mathbf{2}$, urea/thiourea $\mathbf{3}$ and an amine $\mathbf{4}$, in the presence of lanthanum chloride undergo solvent free reaction under microwave irradiation (Scheme 1).a four-component reaction to afford polysubstituted imidazoles (Scheme 1, Table 2). ${ }^{1} \mathrm{H}$ NMR analysis of the reaction mixtures clearly indicated the formation of the corresponding imidazoles $\mathbf{5 a - i}$ in excellent yields. All products were characterized by ${ }^{1} \mathrm{H}$ and ${ }^{13} \mathrm{C}$ NMR spectroscopy and by comparison of their spectral data and melting point values with those of the authentic samples reported in the literature. Results of these successive reactions are shown in Table 2.

A mechanistic rationalization for the reaction is provided in Scheme 2. In this pathway the lanthanum chloride activates the carbonyl groups to promote the reaction.

Table 2. Synthesis of 1,2,4,5-tetrasubstituted imidazole derivatives.

\begin{tabular}{lllcl}
\hline $\mathbf{5}$ & $\mathrm{R}$ & $\mathrm{R}^{\prime}$ & \% Yield & $\mathrm{mp}\left({ }^{\circ} \mathrm{C}\right)(\mathrm{lit})$ \\
\hline a & $\mathrm{Ph}$ & $\mathrm{Ph}$ & 83 & $219-221(220)^{11}$ \\
b & $4-\mathrm{OMeC}_{6} \mathrm{H}_{4}$ & $\mathrm{Ph}$ & 82 & $183-185(183-184)^{8}$ \\
c & $2-\mathrm{OHC}_{6} \mathrm{H}_{4}$ & $4-\mathrm{MeC}_{6} \mathrm{H}_{4}$ & 85 & $228-229(227-229)^{9 b}$ \\
d & $4-\mathrm{NO}_{2} \mathrm{C}_{6} \mathrm{H}_{4}$ & $4-\mathrm{MeC}_{6} \mathrm{H}_{4}$ & 90 & $219(217-219)^{10}$ \\
e & $4-\mathrm{ClC}_{6} \mathrm{H}_{4}$ & $4-\mathrm{ClC}_{6} \mathrm{H}_{4}$ & 86 & $188-190(189-190)^{9 b}$ \\
f & $2-\mathrm{OHC}_{6} \mathrm{H}_{4}$ & $\mathrm{Ph}$ & 92 & $256(254-256)^{8}$ \\
g & $3-\mathrm{NO}_{2} \mathrm{C}_{6} \mathrm{H}_{4}$ & $4-\mathrm{MeC}_{6} \mathrm{H}_{4}$ & 88 & $150-152(150-151)^{10}$ \\
h & $4-\mathrm{NO}_{2} \mathrm{C}_{6} \mathrm{H}_{4}$ & $\mathrm{Ph}$ & 94 & $191-192(190-192)^{14}$ \\
i & $4-\mathrm{ClC}_{6} \mathrm{H}_{4}$ & $\mathrm{Ph}$ & 93 & $153-154(152-154)^{11}$ \\
\hline
\end{tabular}

${ }^{\mathrm{a}}$ Isolated yield after recrystallization.

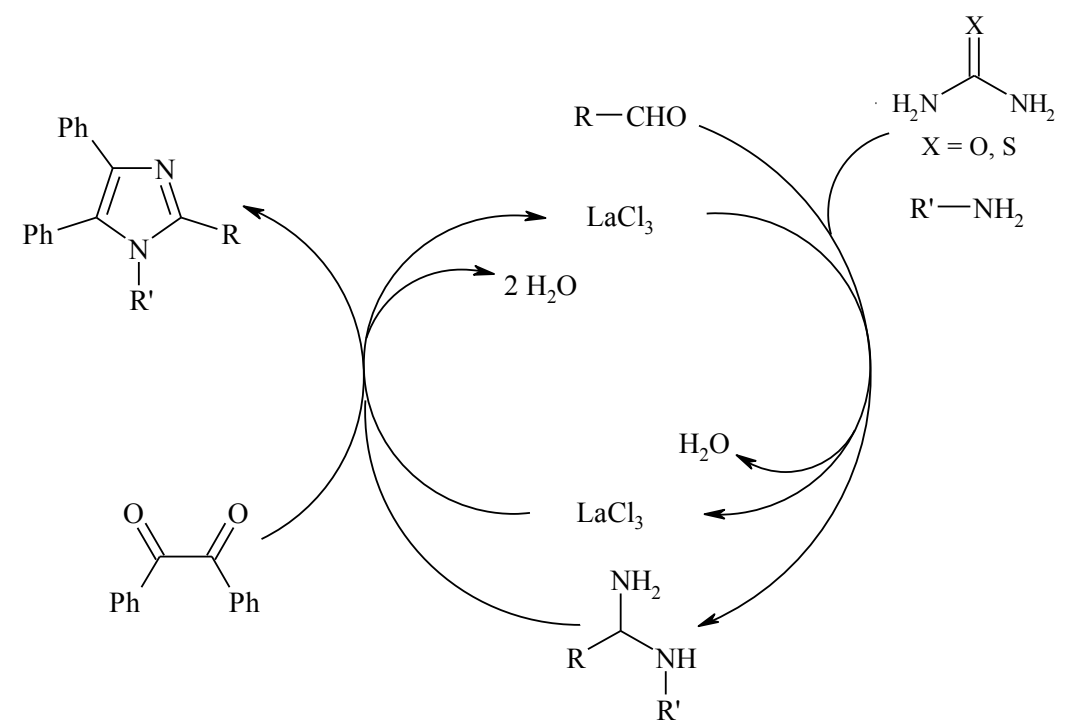

Scheme 2. Proposed mechanism for the current reaction. 


\section{Conclusion}

In conclusion, we have developed a facile and novel strategy for the preparation of polysubstituted imidazoles which are of potential synthetic and pharmacological interest. We have successfully demonstrated the utility of urea/thiourea as an environmentally benign source of ammonia for imidazole synthesis under microwave irradiation. The utility of urea/thiourea as a source of ammonia represents an alternative and novel method for imidazole synthesis with respect to known methodologies using ammonium acetate. Use of commercial materials, solvent-free conditions, short reaction times, excellent yields of the products are the main advantages of this method.

\section{Acknowledgments}

Support of this investigation by the Islamic Azad University Tehran south branch through grant is gratefully acknowledged.

\section{References}

1. Lee J C, Laydon J T, McDonnell P C, Gallagher T F, Kumar S, Green D, McNulty D, Blumenthal M J, Keys J R Vatter S W L, Strickler J E, McLaughlin M M, Siemens I R, Fisher S M, Livi G P, White J R, Adams J L and Young P R, Nature, 1994, 372, 739.

2. Takle A K, Brown M J B, Davies S, Dean D K, Francis G, Gaiba A, Hird A W, King F D, Lovell P J, Naylor A, Reith A D, Steadman J G and Wilson D M, Bioorg Med Chem Lett., 2006, 16, 378.

3. Khanna I K, Weier R M, Yu Y, Xu X D, Koszyk F J, Collins P W, Koboldt C M, Veenhuizen A W, Perkins W E, Casler J J, Masferrer J L, Zhang Y Y, Gregory S A, Seibert K and Isakson P C, J Med Chem., 1997, 40, 1634.

4. Gallagher T F, Fier-Thompson S M, Garigipati R S, Sorenson M E, Smietana J M, Lee D, Bender P E, Lee J C, Laydon J T, Griswold D E, Chabot-Fletcher M C, Breton J J and Adams J L, Bioorg Med Che. Lett., 1995, 5, 1171.

5. Newman M J, Rodarte J C, Benbatoul K D, Romano S J, Zhang C, Krane S, Moran E J, Uyeda R T, Dixon R, Guns E S and Mayer L D, Cancer Res., 2000, 60, 2964.

6. Antolini M, Bozzoli A, Ghiron C, Kennedy G, Rossi T and Ursini A, Bioorg Med Chem Lett., 1999, 9, 1023.

7. Wang L, Woods K W, Li Q, Barr K J, McCroskey R W, Hannick S M, Gherke L, Credo R B, Hui Y H, Marsh K, Warner R, Lee J Y, Zielinsky-Mozng N, Frost D, Rosenberg S H and Sham H L, J Med Chem., 2002, 45, 1697.

8. Kidwai M, Mothsra P, Bansal V, Somvanshi R K, Ethayathulla A S, Dey S and T. Singh P, J Mol Catal A: Chem., 2007, 265, 177.

9. Heravi M M, Derikvand F and Bamoharram F F, J Mol Catal A: Chem., 2007, 263, 112.

10. Kantevari S, Vuppalapati S V N, Biradar D O and Nagarapu L, J Mol Cata A: Chem., 2007, 266, 109.

11. Sadeghi B, Mirjalili B B F and Hashemi M M, Tetrahedron Lett., 2008, 49, 2575.

12. Heravi M M, Derikvand F and Haghighi M, Monatsh Chem., 2008, 139, 31.

13. Karimi A R, Alimohammadi Z, Azizian J, Mohammadi A A and Mohammadizadeh M R, Catal Commun., 2006, 7, 728.

14. Samai S, Nandi G C, Singh P and Singh M S, Tetrahedron, 2009, 65, 10155.

15. Wolkenberg S E, Wisnoski D D, Leister W H, Wang Y, Zhao Z and Lindsley C W, Org Lett., 2004, 6, 1453.

16. Borthakur M, Dutta M, Gogoi S and Boruah R C, Synlett, 2008, 20, 3125.

17. Khabazzadeh H, Saidi K and Sheibani H, Bioorg Med Chem lett., 2008, 18, 278. 


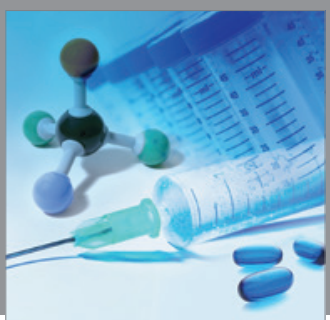

International Journal of

Medicinal Chemistry

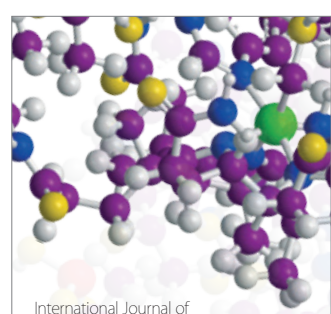

Carbohydrate Chemistry

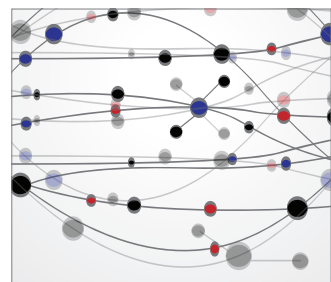

The Scientific World Journal
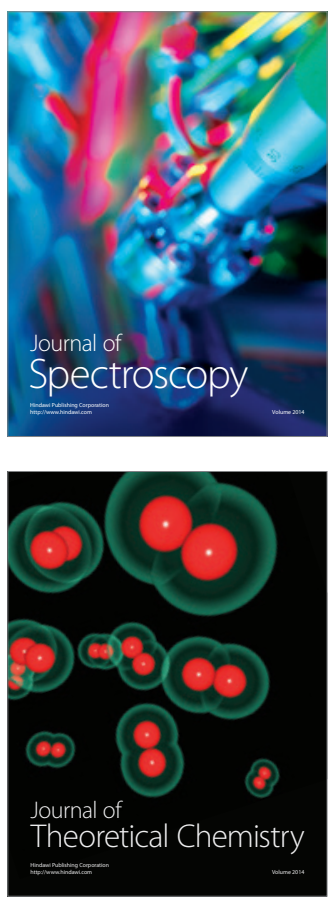
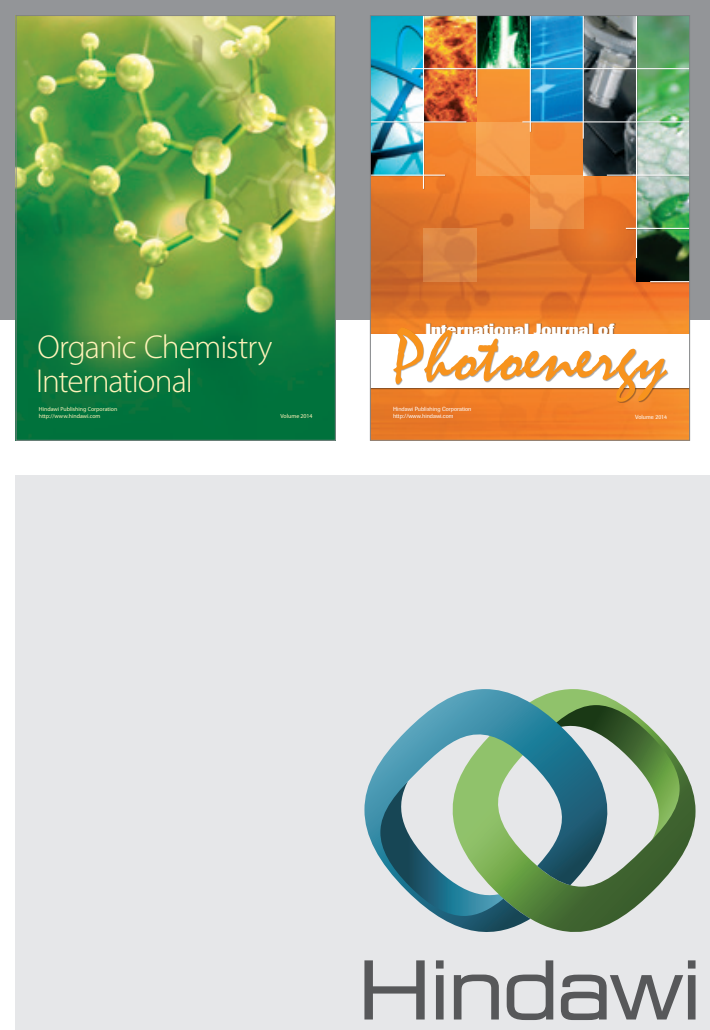

Submit your manuscripts at

http://www.hindawi.com
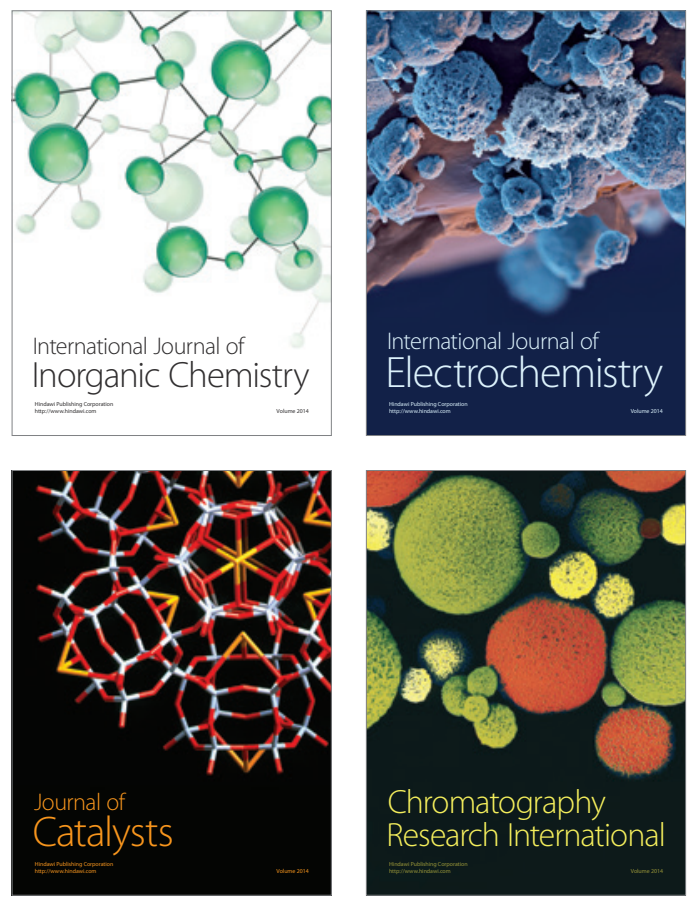
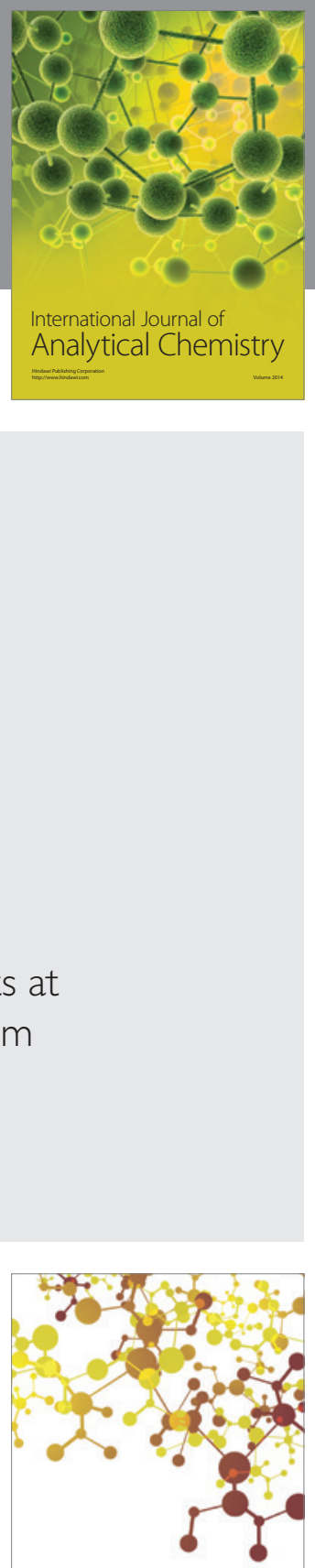

Journal of

Applied Chemistry
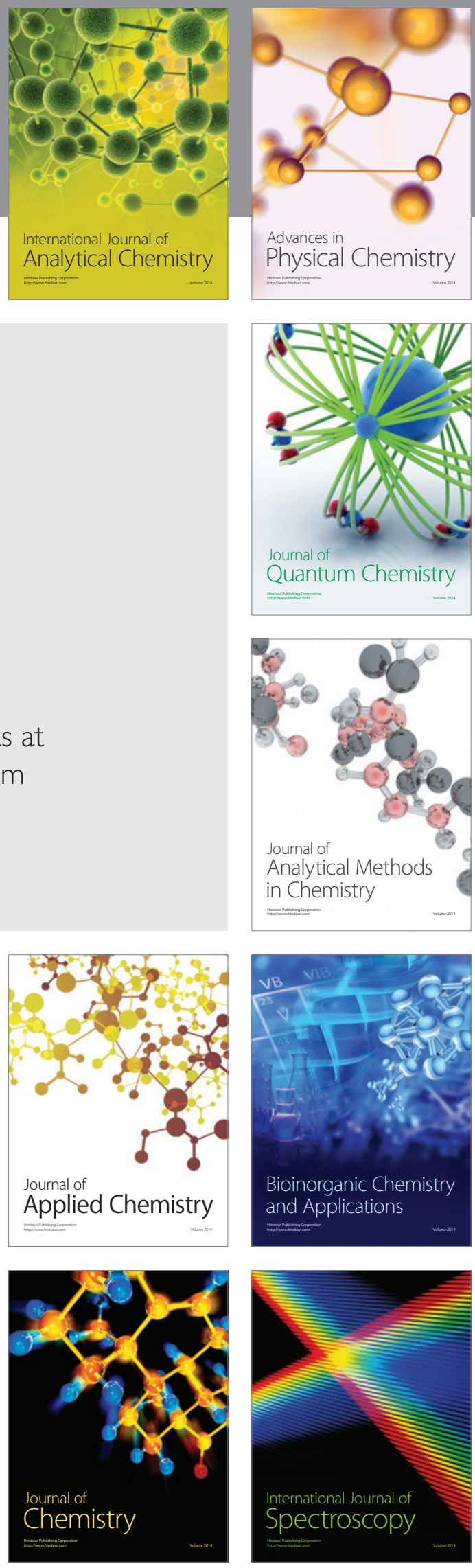